\title{
LEXICAL SELF-CORRECTION IN SPEECH BEHAVIOUR ${ }^{1}$
}

\author{
Anna E. Tsesarskaya \\ Far Eastern Federal University, Vladivostok, Russian Federation
}

\begin{abstract}
Self-correctoin phenomenon in oral speech is the result of speaker's control. Speaker views his / her utterance as according or not to initial purpose (precision of information, correspondence to standard language and so on) and if it is necessary corrects him / herself. So, self-correction is a double denotation of the same situation (to the speaker's mind), which consists of two elements - error word and repair word. In this study the author makes an attempt to submit and analyze self-correction in colloquial speech as a phenomenon manifesting basic concept of arrangement of language knowledge in a speaker's conscience. The paper presents the classification of types of lexical self-correction in spontaneous oral speech. Components of self-correction (error word and repair word) are words of similar form and / or meaning. Those elements can be synonymous, antonymous, hyperonymous, derivational correlates or they may have similar opportunities and / or grammar features. Moreover, error word and repair word can be linked only in the context. The study results confirm the fact that the self-correction is a typical feature of spontaneous colloquial speech and it is manifesting a speech production process. The research was conducted on the basis of large corpus of spontaneous self-corrections of Russian speakers.
\end{abstract}

Key words: linguistic consciousness, mental lexicon, colloquial speech, self-correction, lexical self-correction.

УДК $81-25$

ББК 81.055 .51 .12
Дата поступления статьи: 01.07.2016 Дата принятия статьи: 08.11.2016

\section{ЛЕКСИЧЕСКАЯ АВТОКОРРЕКЦИЯ В РЕЧЕВОМ ПОВЕДЕНИИ ГОВОРЯЩЕГО ${ }^{1}$}

\author{
Анна Евгеньевна Цесарская \\ Дальневосточный федеральный университет, г. Владивосток, Российская Федерация
}

\begin{abstract}
Аннотация. Автокоррекция в разговорной речи обусловлена, с одной стороны, особенностями спонтанного протекания последней, с другой - сознательным отношением говорящего к собственному речевому поведению. Если качество речи оценивается говорящим как неудовлетворительное (с точки зрения информативности, нормы), он корректирует свое высказывание. Таким образом, автокоррекция отражает динамику речемыслительного процесса как процесса творческого. В данном исследовании автокоррекция в разговорной речи рассмотрена как феномен, отражающий основные принципы организации языковых знаний в сознании говорящего. Представлена классификация и описание типов лексической автокоррекции в устной речи, компонентами которой являются единицы, входящие в различные парадигматические ряды (синонимические, антонимические, гипонимические, ассоциативные, паронимические, деривационные и т. д.), а также объединяющиеся на основе синтагматических свойств ○ (общности валентных возможностей, грамматических характеристик, контекстуальной обусловленности), то есть находящиеся между собой в отношениях смыслового и / или формального тождества противопоставления. Поскольку автокоррекция представляет собой двойную вербализацию, как правило, одной референтной ситуации (с точки зрения говорящего), она становится отражением такой особенности разговорной речи, как вариативное выражение значения. Это позволяет сделать вывод о том, че что автокоррекция является типичной чертой разговорной речи.

Ключевые слова: языковое сознание, внутренний лексикон, разговорная речь, автокоррекция, лексическая автокоррекция.
\end{abstract}


1

Автокоррекция как феномен разговорной речи имеет психолингвистическую природу и является отражением процесса речевого самоконтроля; в ней проявляются такие типические черты разговорной речи, как спонтанность, с одной стороны, и направленность на адресата - с другой [9, с. 5-19]. Желание быть услышанным, понятым собеседником вступает в противоречие с характером порождения устной речи, поскольку «для разговорной речи характерно напряжение между линейным развертыванием речи и формированием содержания» [9, с. 34-35]. «Сложность языковой системы обусловливается прежде всего бесконечным многообразием отражаемой в нашем сознании действительности» [16, с. 11], поэтому задачу построения высказывания затрудняет говорящему и тот факт, что из всего многообразия языковых средств он должен выбрать именно то, которое максимально отвечает его замыслу. Сложность языкового выбора, перед которым стоит говорящий, ведет к появлению в речевой цепи разного рода хезитаций, поправок, уточнений, перестроек высказывания «в режиме реального времени» и т. д.

В психолингвистических исследованиях автокоррекция упоминается в связи с вопросами порождения высказывания и организации лексикона в сознании человека $[3 ; 6 ; 7 ; 11$; $15 ; 16 ; 19]$. Она появляется в речи как реакция на сбой в коммуникативной программе, возникший в результате ослабления контроля над процессом речепроизводства. «Она совершенно естественна и отражает реальный процесс поиска и выбора лексемы» [16, с. 39]. Исследователи указывают на психолингвистическую природу автокоррекции как особенности живой устной речи, звучащей и формирующейся в соответствии с механизмами продукции спонтанного речевого выказывания и являющейся результатом сознательного контроля за качеством речи $[1$, с. $304 ; 13$, с. 17].

Очевидна ценность изучения явления автокоррекции в направлении «“"от общих закономерностей коммуникации" - для выяснения общих закономерностей устройства механизма, позволяющего осуществить коммуникацию» [18, с. 221]. При этом подходе автокоррекция может рассматриваться не толь- ко в качестве «отрицательного языкового материала» (Л.В. Щерба), но и в качестве обязательного материала для изучения закономерностей речевой деятельности как таковой, позволяющего исследователю «заглянуть» в глубины человеческого сознания, попытаться понять принципы устройства языковой памяти - того слоя человеческого сознания, который «оперирует значимыми элементами конкретного национального языка» $[6$, с. 12] и который отвечает за «хранение и извлечение знаний языка в процессах речи» [12, с. 82]. В лингвистической литературе это явление описывалось как коммуникативная память [5], ассоциативно-вербальная сеть [10], внутренний лексикон [11], грамматика говорящего [16]. В рамках этого подхода автокоррекция, наряду с другими типами хезитаций, является для исследователя отражением динамики речемыслительного процесса как процесса творческого, «в ходе которого замысел получает не просто некую объективированную языком форму, - он проясняется, уточняется и конкретизируется» [11, с. 33]. Таким образом, автокоррекция эксплицирует процесс рождения знания, что является подтверждением тезиса Л.С. Выготского о том, что «мысль не выражается в слове, но совершается в слове» $[4$, с. 305$]$.

Цель данной статьи - выявить особенности лексической автокоррекции (слово слово / словосочетание), которая представляет собой замену одной лексической единицы (слова или словосочетания) другой, более адекватной замыслу высказывания, например: Хочется еше отметить что студе... аспиранты нашей кафедры выступали с докладами; Они оба с Лесозаводска... ну с Ружсино; Представьтесь... вернее напомните свое имя; По статистике никто не используют поошрительные баллы / потому что хотят... боятся нарушить что-то; Больше всего мне понравился... ну... впечатление оставил / потом увидите почему / Диснейленд; Я свою (дочь) пичкаю, пичкаю... ну в смысле как... нормально кормить стараюсь; Ко мне невестка пристала.. жеена брата... кто она там... золовка не знаю; // Значит / десять штук душистого периа / пять гвоздик / пять кории... нет... не пять кории / а на кончике ножа корица. 
Исследование проведено на материале записей живой разговорной речи (объем - около 2000 языковых фактов; сбор материала осуществлялся с 2005 по 2015 г.; информантами являются образованные носители русского литературного языка - жители Приморского края).

\section{2}

Корректируемое и корректирующее лексической автокоррекции находятся в парадигматических отношениях противопоставления или сближения - смыслового и / или формального.

2.1. Бо́льшая часть зафиксированных в нашем материале автокоррекций «слово слово / словосочетание» - это семантические корреляции на основе синонимии.

Отношения синонимии связывают слова, характеризующиеся значительным (или полным) совпадением в объеме своего лексического значения. Компонентами лексической автокоррекции могут быть точные (абсолютные) синонимы, отличающиеся, например, сферой употребления (общеупотребительные, профессиональные, жаргонные и т. д.): Маститыми мы считаем тех адвокатов / которые появляются в ящике... на телевидении; У нас в Лесозаводске был БХЗ... биохимический завод; происхождением (заимствованные - исконные): Здесь два корня / антропо... то есть человек; а также стилистические синонимы: Может «Мария-Прим» сдо... (*сдохла) ой (хихикнул) померла.

В подавляющем же большинстве корректируемое и корректирующее, образующие синонимическую пару, не являются идентичными в плане содержания, а представляют собой лексемы, в разной степени совпадающие по значению. Так, в приведенных ниже автокоррекциях первая и вторая вербализации отличаются друг от друга порой едва различимыми оттенками смысла:

- (ребенку) Видишь / она (собака) коnает лапками... pоeт (ср.: копать - «1. разрыхлять почву лопатой или другим орудием, перебрасывая отделившиеся комья на соседнее место или переворачивая их. 2. делать углубление, выемку, вынимая, отваливая зем- лю; рыть. 3. роя, доставить, извлекать (из земли)», pыть - «1. Делать в земле яму, углубление и т. п.; копать. 2. ковырять, разрывать» ${ }^{2}$; у лексем копать и рыть совпадают архисемы, поскольку эти глаголы выражают значение «делать яму, углубление в земле», но различаются некоторые дифференциальные признаки: копать имеет семы 'орудием', 'не хаотично, вынимая землю'; следовательно, коnamb не может обозначать действие, выполняемое животным);

- Русские очень нетерпимы к дру... (*другому) чужсому (чужой - это не просто не такой, как я, в отличие от другой, но и посторонний, далекий; ср.: чужой - «1. не имеющий непосредственного отношения к комул.; не свой. 2. не являющийся родиной. 3. не связанный родственными отношениями; посторонний. 4. не связанный близкими отношениями с кем-л., не совпадающий по духу, взглядам, интересам; посторонний, далекий», $р p y$ гой - «1. не этот, не данный. 2. противоположный (о береге, стороне чего-л.). 3. не такой, как этот (или прежний); иной»);

- Вот / Люда ходила / она мне кричит / вам надо (помидоры)? А я говорю / давай / у меня пропали все... сгнили (ср.: проnасть - «погибнуть, умереть», сгнить - «разрушиться, подвергнувшись гниению»).

Для говорящего едва уловимая разница в словарных значениях становится в некоторых случаях существенной настолько, что приводит к переходу синонимов в разряд контекстуальных антонимов. Корректировка при этом сопровождается специальными маркерами «зачеркивания»:

- Дети из интерната идут // Без родителей // Там половина лии ясно... родители... вернее очевидно / кто родители (ср.: ясно - «понятно, несомненно, безусловно (совершенно очевидно, не вызывает сомнений)», очевидно - «1. ясно, понятно. 2. вероятно, повидимому»; наречия ясно и очевидно противопоставляются по степени проявления называемого признака: ясно обозначает бо́льшую достоверность, чем очевидно;

- Если это узбеки планировали ограбление... ой не ограбление... кражу (говорящим актуализируется противопоставление по признаку «способ похищения»- 'силой' и 'тайно' соответственно); 
- (шутливо об уволившемся сотруднике) Нечего было убегать... сбегать я бы даже сказала (противопоставление слов в синонимичной паре убегать, сбегать осуществляется по признаку «уйти от чего-либо неприятного»; ср.: убегать - «1. уйти, удалиться откуда-л. бегом. 2. покинуть кого-, что-л. незаметно, тайком, сбежать; скрыться, исчезнуть», сбежать - «убегать, уходить; совершить побег; уйти откуда-л., избавляясь от кого-, чего-л. неприятного, досадного»).

Корректируемое, как правило, выражает более общую семантику по сравнению с корректирующим: другой - чужой (чужой - это всегда другой (не этот, не такой, как я, не родной), а другой может и не быть чужим), пропали - сгнили (и пропасть, и сгнить - это погибнуть, но в слове сгнить дополнительно содержится указание на «способ» гибели), убегать - сбегать (сбегать в отличие от убегать содержит дополнительный семантический компонент «уйти от чеголибо неприятного»).

Кроме того, вторая номинация может быть осложнена явной оценочностью в сравнении с первой: $A$ че книжка... телефон лежит... валяется (денотативная сторона высказывания осложнена коннотацией «небрежно брошенный»).

В некоторых случаях корректируемое и корректирующее соотносятся как слова с частно- и общеоценочным значением: Приписка есть / все / стоим на очереди (в детский сад) // Очередь мало движется... пло-

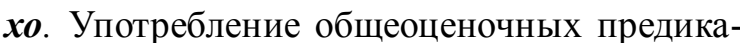
тов «в качестве эквивалентов частных оценок... вторично», поскольку они (слова с общеоценочным значением) «более явственно, чем частные оценки, выражают сопутствующую высказыванию иллокутивную силу рекомендации или одобрения, запрета или осуждения» [2, с. 194].

Таким образом, первое слово зачастую оказывается семантически шире второго, и говорящий, актуализируя различия между двумя лексическими единицами, конкретизирует, дополняет смысл сказанного, то есть ищет более точную форму словесного обозначения для выражения своей мысли.

Семантическое тождество корректируемого и корректирующего может быть обус- ловлено совпадением их плана содержания в одном из лексико-семантических вариантов, например: $О н$ (мост) горит... светится по ночам.

2.2. Компоненты автокоррекции могут иметь семантическую общность на основе антонимии. Отношения антонимии предполагают противопоставление по какому-либо дифференциальному признаку значения слов антонимической пары при совпадении его интегральных компонентов (архисемы): Издесь можно двигаться в сторону национализации / когда... э-э-э... в сторону приватизации когда-то; Как плохо... вернее... как хорошо быть филологом; А впереди народ начинает моргать / что она налево едет... ой направо; Я знаю барабаншиков / которые на менее... на более скромных установках играют; Если мы имеем дело со сложным... с простым предложением; Там стройка идет / много / неплохих конечно / но не таких уж и красивых по архитектуре ваг... (*вагончиков) не вагончики / а пластик (слово вагончик в лексиконе говорящего употребляется, видимо, только для обозначения сооружений из металла, именно по этому признаку оно и противопоставлено слову пластик, то есть в данном фрагменте речи вагончик и пластик - контекстуальные антонимы).

Отношение противопоставления может быть выражено по принципу конверсии (обратная ролевая структура), тогда корректируемое и корректирующее являются лексическими конверсивами: Они (макароны) горячие / щзас осту... (*остужу) остынут.

Смысловое противопоставление корректируемого и корректирующего имеет место не только при антонимической номинации, но и в случае, когда одна номинация представляет собой отрицание другой: Хаммер - это военная машина американская... вернее она не военная / была военная; "Я читал об этом вчера» - обобщенно-фактическое значение // "Я прочитал об этом вчера»тоже конкретно-фактическое значение... вернее не тоже; Я плохо знаю историю Индии.. вернее вообще не знаю; (ребенку, выронившему из рук машинку, которую он нашел на площадке) Вот она твоя машина... ну она не твоя конечно; Когда в войну 
вступила Россия с Японией / нам еще восемнадцати не было... нет... извиняюсь... было / потому что это было тринадияатого мая // Это было восемнадиатого / а война началась в августе - сентябре / так что восемнадиать лет и что-то там.

2.3. При автокоррекции семантические объединения лексики на основе синонимии / антонимии не являются исчерпывающими. Компоненты автокоррекции могут быть связаны парадигматическими отношениями иного плана - включения («род - вид», «часть целое») или соположенности.

В случае реализации соотношения «род вид» корректируемое и корректирующее соотносятся как гипероним и гипоним: Люди обратили внимание... ученые обратили внимание; Вот этот который... этот самыии... сельскохозяйственный техникум кончил в деревне... работал... преподавал это... курсанты молодые училися у него; Нет / он может свои / это самое / о спорте (рассказать) / он же боксер / правда он в армии не служил / но спортсмен... боксер; $A$ я не помню / когда родители научили меня читать... мама научила; И костюм не будет... пиджсак видно из-за нее (куртки).

В подавляющем большинстве автокоррекций корректируемое по семантическому объему шире корректирующего. Тем не менее в нашем материале есть примеры, где наблюдается обратное соотношение: Это же ведь ну просто уму непостижимо / что на территории Чеховского района / на территории психиатрической больницы / которая э-э-э там сто гектар леса / отбирают / отбирают для постройки коттеджсй... ну жилья; Не в состоянии один человек... я имею в виду одно семейство / у которого будет собственность / оно не может реконструировать / э-э как раз возобновление вот этих вот природных богатств. Таким образом, в качестве первой вербализации, как правило, употребляется более простое, общее по смыслу слово, лишь затем говорящий заменяет его на более конкретное (принцип поля).

В случае соположенности лексические элементы автокоррекции являются согипонимами: Ага // На прошлой неделе (купили куртку) в среду... ой в субботу; Надо заехать бензин... тьфу... масло поменять заехать; Масло купить надо. - Кого? - Ну масло сливочное... ой растительное; Она (дочка) жука испугалась // В Мухе-Цокотухе жук... ой паук... муху уволок; Сроки уплаты транспортного налога... о-ой... земельного налога до пятнадиатого ноября.

2.4. Компоненты автокоррекции в приведенных ниже случаях связаны семантическими отношениями ассоциативно: Mbl сегодня решили... короче... вернее... я подумала и мы решили (смеется) поехали на автодром; Она на две головы его выше по способностям... ну не по способностям... по возможностям («От каждого - по возможностям, каждому - по способностям»).

2.5. Компонентами автокоррекции могут оказаться слова, план содержания которых имеет небольшую зону пересечения, когда совпадение затрагивает только периферийную часть их значений (архисемы при этом различаются):

- Ну скажем так / пейзаж в Хабаровске... вернее смотровая (видимо, имеется в виду видовая площадка) в Хабаровске не впечатляет (объединяющими слова пейзаж и смотровая являются семы 'вид', 'смотреть');

- Обратно ты ж без нее (сумки) поедешь... в смысле она пустая будет (общая потенциальная сема - 'налегке', поскольку без указывает на отсутствие кого-, чегол., а пустой - на незаполненное, не занятое кем-, чем-л. пространство);

- Bo-nервых mут (на детской площадке возле дороги) заnах такой... воздух (общая сема у компонентов автокоррекции - 'дыхание', ср.: заnаx - «свойство веществ, воспринимаемое обонянием», обоняние - «способность к восприятию и различению запахов (одно из пяти внешних чувств)», нюхать «вдыхать через нос с целью ощутить, распознать запах», воздуx - «смесь газов, из которых состоит атмосфера Земли; дыхательная среда человека, живого организма»).

Первым из двух компонентов автокоррекции является тот, в котором общая сема занимает ближайшее к центральной зоне значения положение (так, компоненты 'вид', 'смотреть' входят в ядерную зону значения слова пейзаж и в периферийную - слова 
смотровая; сема 'налегке' входит в периферийную зону компонентов без и пустая), то есть изначально в сознании говорящего возникает слово, наиболее синкретично выражающее замысел высказывания, а уже затем происходит вычленение отдельных элементов смысла (например, место, откуда можно любоваться видом). Данное наблюдение подтверждает тезис о полевом принципе организации внутреннего лексикона человека $[8 ; 9$; $11 ; 16 ; 17 ; 19]$. Подобные автокоррекции свидетельствуют о динамичности языковой памяти говорящего, проявляющейся в неразрывности системных связей ее единиц.

2.6. Компонентами автокоррекции могут являться однокоренные слова (синонимы, антонимы, согипонимы), в таком случае они характеризуются не только семантической и / или формальной общностью, но и деривационными отношениями, в частности отношениями словообразовательной производности. При этом корректируемое и корректирующее могут быть представлены дериватами одной части речи (В прошлом году мама пересадила его (клематис)... в позапрошлом; Его (овес) жсарили... поджаривали / чтоб коричневым был... и... мололи / и заваривали; Тебе всю головку чистить? - Пару тройку зубков... зубцов; М. переусердствовала вчера... позавчера вернее) или характеризоваться разной частеречной принадлежностью (Освобождение от Испании... от испанских колонизаторов; $\mathrm{Mbl} в$ прошльй раз по неврологу ходили... по неврологии; Нелегальные (мигранты) - незаконные // Te / которые нарушили законодательное... законодательство; Мне четырнадиатую $и$ пятнадцатую (страницу) в двойном... в двух экземплярах).

В паре корректируемое - корректирующее словообразовательным производным, как правило, является корректируемое: Ну где-то по середине деревни река текла / небольшая река... речушка небольшая такая; Ну / Тихоокеанский тоже строится / вот... paccmpaивается; (Одевает ребенка. Чтобы было удобнее, переложила яблоко из одной руки ребенка в другую. Ребенок требует отдать ему яблоко) Я же не беру... не забираю y тебя яблоко; Там в вокзале узнайте расписание... в автовокзале; Ну она ж одна... одинокая. Автокоррекции с производным корректирующим немногочисленны: $O$ н парочку раз поиграл... пару раз на площадке (каталкой); Уберите все со столов // Пожалуйста // Только ручка и листок бумаги... лист бумаги; Сможет он ее (задачу) порешать... ну решить.

В некоторых случаях автокоррекция представляет собой морфемное чередование, когда в семантические корреляции разного рода вступают части слов - словообразовательные форманты: Заходи... то есть выходи; Машинку (стиральную) ж надо загрузить... разгрузить; (о ребенке) - Он (ребенок) мокрый. - Да я его не одевал. - Не / пописал в смысле. - Пописал... прописал памперс; Их иель / провести дог... (*договоры) переговоры чтобы заключить договор; А в колхозах ведь... че-то я не знаю... тогда Сталин выписал... или как сказать написал брошюру «Головокружение от успехов» название / от что сделали это на местах местная власть; Tbl запиши на листочке // Я домой приду перепишу.. запишу // Просто я могу забыть.

2.7. Сходство плана содержания компонентов автокоррекции зачастую сопровождается сходством плана выражения, например, при использовании паронимов, а также в случае лексической вариантности (произносительные, акцентологические, лексические варианты): Еда такая штука знаешь // Тем более в консервном... консервированном виде // He пропадет; Какая-то непонятно маниакальная экономика... экономия вернее... средств; Например / космические... космологические понятия времени / пространства; Ты че... что делаешь? Надо тышу.. тысячу знаков; Там статья / перевести надо // И подискуссировать на эту тему... подискутировать; Удивительно // С тво́рогом... с творого́м вареники есть только компании «Ратимир»; И ва́реный тоже... варёный едят (рис). В автокоррекциях корректируемое и корректирующее могут быть сходны лишь по звуковому и / или морфемному составу. «Чистое созвучие» первой и второй вербализаций представлено в следующих примерах: Ну ты в ванне полежи / чтоб отечность с морды спала́... спа́ла; Ничего не могу изменить / потому что этот кальмар... этот 
карман неглубокий; У меня глаза постоянно красные // Я их уже бензином... ой... визином заливаю; Ну там огорода немножко / потом он / делал / вот / аб / обрыв такой это / город... этой... горы; (о том, что в салоне автомобиля жесткие сиденья) На тебе табуретку и ешь... езжай.

Звуковое сходство компонентов автокоррекции может осложняться сходством морфемного состава, например: - Картошку с кожурой варить или чистить? - Если ту которую ты сегодня выкупал... выкопал / тогда с кожурой; Слова... это не значит ничего // Важно инту... (*интуиция) интонация; Девочки / если кто-то приносит дискеты / бегите... берите; Это публикаичия // Планируется как раздел главы // Нет включения заключения... ой... вступления; Промышленные предприятия загружа... загрязняют окружаюшую среду.

2.8. Парадигматически противопоставленными в корректировочной конструкции могут быть не только знаменательные, но и служебные части речи: $B$ вену колят от сердиа... для сердиа; (шутливо о ребенке) Щас я этого парня поймаю / а то он в постели на бо... в ботинках; Tbl в его... на его месте так же бы поступил; - Зачем ты ему (ребенку) кашу дал? - Он сам взял. - А зачем ты позволил чай на нее... в нее лить?

Итак, компоненты автокоррекции в парадигматическом плане представляют собой корреляции, входящие в следующие типы лексических оппозиций: нулевая (абсолютные синонимы), эквиполентная (синонимы, антонимы, паронимы, согипонимы), привативная (гипероним - гипоним).

Тождество / противопоставление корректируемого и корректирующего необязательно обусловлено связью парадигматического характера, оно может реализоваться синтагматически.

В следующих автокоррекциях сходство первой и второй номинации основано на свойствах синтагматического плана, например, на общности валентных возможностей слова: А вот здесь... на русском языке... на Русском острове нет бассейна для детей; (об- суждают цены на билеты) Это если на скорой пом... тьфу... на скором поезде ехать... (смеется) на скорой помощи (смеется); Змеи способны погружать состояние... сознание человека в некий транс (погружаться в состояние - погружать сознание).

Синтагматический фактор влияет и в том случае, когда элементы корректирующей конструкции связаны речевым контекстом, то есть оба слова являются частью замысла высказывания, но в результате ослабления контроля над процессом речепроизводства одно из слов употреблено в речи раньше, чем нужно: Не по существу / значит вопрос... ответ не связан с вопросом; Так / мне завтра в девять тридиать надо быть // Надо с утра сумку сразу... тетрадь в сумку положить; - Че ногти такие длинные? - Да нет у меня подстригалки // - Дал бы... сказал бы / я б тебе дала; Активно... вернее понятно / что ты активно болеешь. Случаи «опережающей вербализации» свидетельствуют о синкретичности замысла (в противопоставлении линейности речи): «то, что в мысли содержится симультанно, в речи развертывается сукцессивно» [4, с. 356].

Иногда корректируемое представляет собой «лексический подхват», поскольку «говорящий может выбрать те или иные слова или конструкции исключительно потому, что они только что были употреблены в чужой или в его собственной речи» $[14$, с. 35$]$ : (аттестация дипломных работ на заседании кафедры) - А обращчение (Дерсу Узалы) «капитан» / только к Арсеньеву или к другим мужчинам этой экспедиции? - Только к Арсеньеву // - Ну он (Арсеньев) же капитан... вернее он военный.

Между двумя вербализациями может устанавливаться особого рода связь - конситуативная, выявляемая только при обращении к контексту: Он называется Дальневосточный форум инициативной молодежи «Андреевский городок» // И когда набираешь «форум инициативной молодежи», выскакивает "Андреевская молодежь»... «Андреевский городок»; Где аквамарис? Ну в смысле физраствор (во флакон из-под «Аквамариса» налит физраствор). В некоторых случаях компоненты корректирующей конструкции, связанные конситуатив- 
но, могут образовывать словосочетание: $H y$ аниковский автодром (автодром автошколы «Аник») / вот здесь у них стоят машины / все такое // Tb заходишь / денежку платишь и тебя с инструктором ездят... учат (*учат ездить); Это (насморк) связано с аллергией... с цветением (*аллергия на цветение); Выключай телефон... звук (*звук на телефоне). Такие автокоррекции свидетельствуют о подвижности внутреннего языкового устройства, что проявляется в неразрывности парадигматических и синтагматических связей единиц языковой памяти.

\section{4}

Корректируемое и корректирующее, как правило, характеризуются как грамматически однородные: Я уже не представляю / сколько я часов... да уже какой часов... уже месяцев пять наверное прожил в автобусе за пять лет / ну а че два часа каждый день, как минимум; Я уже в колхозе заведуюшая была овиеводческой фирмы... фермы / в колхозе... уже был... за овечкой ходила (смеется); Я тоже когда на площадке с ним играю... гуляю / я не могу за игруиками следить; Это у нас там сопля / некрасивая / во рту... в носу. Однако принцип грамматической однородности соблюдается не всегда: Наивная картина мира свойственна обыденному сознанию... то есть ненаучное; Ну и в 59-м призвался в армию / отслужил три года / там на Севере... на Камчатке... Петропавловск-Камчатский; У него холоднее... вернее... что теплее холодной воды / горячая; Порошенко жаловался что Путин стал ему реже звонить / после приезда в Австралию... точнее отъезд из Австралии; Отстегни мой телефон // Там / на зарядке // Сколько там времени... вернее... заряд.

В некоторых случаях говорящий при осуществлении корректировки, так и не найдя нужного слова, прибегает к его семантизации через описание ситуации, то есть употребляет в качестве корректирующего синтаксическое целое (которое можно заменить одним словом / словосочетанием): Я знаю / он когда в ФСБ работал / полиграф на наркоте засыпался... то есть на вопрос «Принимал наркотики" / сказал "нет» / а полиграф показал "да» (= попался на лжи); Ушла квартира за $3650 \ldots$ вернее... в Интернете висела квартира как у нас / за 3650 // А сейчас не висит (= продана или снята с продажи); А наши дети очень ленивые / очень ленивые... то есть чуть тренер прикрикнет они такие уже своевольные / своенравные // Тренер на него кричит - я не буду этим заниматься (в последнем примере говорящий после описания ситуации находит необходимое ему слово). Корректирующее представляет собой неоднословную номинацию, содержащую в себе функциональное описание референта [9, с. 49]. Данные факты подтверждают действие в устной разговорной речи принципа превалирования смысла над формой, который «позволяет говорящему в целях максимально точного и конкретного донесения смысла до слушающего пренебречь ригористическими требованиями соблюдения точности речевой формы и отступить от нормативных установлений» [13, с. 57-58].

\section{5}

Итак, проведенное исследование доказывает, что:

1) автокоррекция в разговорной речи - это следствие вариативного выражения смысла;

2) автокоррекция в спонтанной устной речи является способом поэтапного формирования смысла в процессе говорения;

3) автокоррекция как типичное явление спонтанной устной речи вскрывает многомерные связи, пронизывающие внутренний лексикон человека;

4) компонентами лексической автокоррекции являются единицы, входящие в различные парадигматические ряды (синонимические, антонимические, гипонимические, деривационные и т. д.), а также объединяющиеся на основе синтагматических свойств (общности валентных возможностей, контекстуальной обусловленности), то есть находящиеся между собой в отношениях смыслового и / или формального тождества - противопоставления. Кроме того, корректируемый и корректирующий компоненты могут быть связаны на основе конситуации. В этом отражается языковой системный код говорящего, и он (гово- 
рящий) при продуцировании и рецепции речи действует в рамках этого кода, что отражает связи внутреннего лексикона - грамматики говорящего.

\section{ПРИМЕЧАНИЯ}

${ }^{1}$ Исследование осуществляется при поддержке гранта РГНФ (проект № 16-04-18021е «Полевые исследования живой русской речи в дальневосточном регионе (на материале Приморского края)».

2 Здесь и далее используются толкования, представленные в словаре русского языка под ред. С.И. Ожегова, Н.Ю. Шведовой : Ожегов, С. И. Толковый словарь русского языка / С. И. Ожегов, Н. И. Шведова. - 4-е изд. - М. : Азбуковник, 1999. $1365 \mathrm{c}$.

\section{СПИСОК ЛИТЕРАТУРЫ}

1. Акишина, Т. Е. Явления устно-речевого синтаксиса в устной научной речи / Т. Е. Акишина, Н. М. Краевская // Современная устная научная речь : в 4 т. Т. ІІ. Синтаксические особенности / под ред. О. А. Лаптевой. - М. : НТЦ Консерватория, 1994. - C. 273-324.

2. Аругюнова, Н. Д. Типы языковых значений: Оценка. Событие. Факт / Н. Д. Арутюнова. - М. : Наука, 1988. - 341 с.

3. Ахутина, Т. В. Порождение речи. Нейролингвистический анализ синтаксиса / Т. В. Ахутина. - М. : Изд-во Моск. ун-та, 1989. - 215 с.

4. Выготский, Л. С. Собрание сочинений : в 6 т. Т. 2. Проблемы общей психологии / Л. С. Выготский. - М. : Педагогика, 1982. - 504 с.

5. Горелов, И. Н. Вопросы теории речевой деятельности / И. Н. Горелов. - Таллин : Валгус, 1987. $-196 \mathrm{c}$.

6. Горелов, И. Н. Основы психолингвистики / И. Н. Горелов, К. Ф. Седов. - М. : Лабиринт, 2008. $320 \mathrm{c}$.

7. Жинкин, Н. И. Речь как проводник информации / Н. И. Жинкин. - М. : Наука, 1982. - 160 с.

8. Залевская, А. А. Вопросы организации лексикона человека в лингвистических и психологических исследованиях / А. А. Залевская. - Калинин : Изд-во Калинин. гос. ун-та, 1978. - 88 с.

9. Земская, Е. А. Русская разговорная речь. Лингвистический анализ и проблемы обучения / Е. А. Земская. - 4-е изд., испр. - М. : Флинта : Наука, $2006 .-240$ c.

10. Караулов, Ю. Н. Русский язык и языковая личность / Ю. Н. Караулов. - 3-е изд., стер. - М. : Едиториал УРСС, 2003.-264 c.
11. Кубрякова, Е. С. Модели порождения речи и главные отличительные особенности речепорождающего процесса / Е. С. Кубрякова // Человеческий фактор в языке: язык и порождение речи. - М. : Наука, 1991. - С. 21-81.

12. Кубрякова, Е. С. Особенности речевой деятельности и проблемы внугреннего лексикона / Е. С. Кубрякова // Человеческий фактор в языке: язык и порождение речи. - М. : Наука, 1991. - С. 82-140.

13. Лаптева, О. А. Живая русская речь с телеэкрана. Разговорный пласт телевизионной речи в нормативном аспекте / О. А. Лаптева. - М. : УРСС, $2000 .-520 \mathrm{c}$.

14. Леонтьев, А. А. Факторы вариантности речевых высказываний / А. А. Леонтьев // Основы теории речевой деятельности. - М. : Наука, 1974. - С. 29-35.

15. Лурия, А. Р. Язык и сознание / А. Р. Лурия. - Ростов н/Д : Феникс, 1998. - 416 с.

16. Норман, Б. Ю. Грамматика говорящего / Б. Ю. Норман. - СПб. : Изд-во С.-Петербург. ун-та, 1994. -228 c.

17. Пешковский, А. М. Русский синтаксис в научном освещении / А. М. Пешковский. - М. : Гос. учеб.-пед. изд-во М-ва просвещения РСФСР, 1956. $512 \mathrm{c}$.

18. Сахарный, Л. В. Тексты-примитивы и закономерности их порождения / Л. В. Сахарный // Человеческий фактор в языке: язык и порождение речи. - М. : Наука, 1991. - С. 221-237.

19. Щерба, Л. В. Современный русский литературный язык / Л. В. Щерба // Избранные работы по русскому языку. - М. : Учпедгиз, 1957. - С. 110-129.

\section{REFERENCES}

1. Akishina T.E., Kraevskaya N.M. Yavleniya ustno-rechevogo sintaksisa $\mathrm{v}$ ustnoy nauchnoy rechi [The Phenomena of Oral Speech Syntax in Oral Scientific Speech]. Lapteva O.A., ed. Sovremennaya ustnaya nauchnaya rech: $v 4$ t. T. II. Sintaksicheskie osobennosti [Modern Oral Scientific Speech. In 4 vols. Vol. 2. The Syntactic Features]. Moscow, Konservatoriya Publ., 1994, pp. 273-324.

2. Arutyunova N.D. Tipy identifitsiruyushchikh i predikatnykh slov: Otsenka. Sobytie. Fakt [Types of Identifying and Predicate Words: Assessment. Event. Fact]. Moscow, Nauka Publ., 1988. 341 p.

3. Akhutina T.V. Porozhdenie rechi. Neyrolingvisticheskiy analiz sintaksisa [Generation of Speech. Neurolinguistic Syntax Analysis]. Moscow, Izd-vo Mosk. un-ta, 1989. $215 \mathrm{p}$.

4. Vygotsky L.S. Sobranie sochineniy: $v 6 t$ t. T. 2. Problemy obshchey psikhologii [Collected Works. In 6 vols. Vol. 2. Problems of General Psychology]. Moscow, Pedagogika Publ., 1982. 504 p. 
5. Gorelov I.N. Voprosy teorii rechevoy deyatelnosti [Issues of the Theory of Speech Activity]. Tallinn, Valgus Publ., 1987. 196 p.

6. Gorelov I.N., Sedov, K.F. Osnovy psikholingvistiki [Fundamentals of Psycholinguistics]. Moscow, Labirint Publ., 2008.320 p.

7. Zhinkin N.I. Rech kak provodnik informatsii [Speech as an Information Conductor]. Moscow, Nauka Publ., 1982. $160 \mathrm{p}$.

8. Zalevskaya A.A. Voprosy organizatsii leksikona cheloveka $v$ lingvisticheskikh $i$ psihologicheskikh issledovaniyakh [The organization of the Human Lexicon in Linguistic and Psychological Research]. Moscow, Kalinin Publ., 1978. 88 p.

9. Zemskaya E.A. Russkaya razgovornaya rech. Lingvisticheskiy analiz i problemy obucheniya [Russian Colloquial Speech. Linguistic Analysis and Learning Problems]. Moscow, Flinta Publ., Nauka Publ., 2006. 240 p.

10. Karaulov Yu.N. Russkiy yazyk i yazykovaya lichnost [Russian Language and Language Personality]. Moscow, Editorial URSS Publ., 2003. 264 p.

11. Kubryakova E.S. Modeli porozhdeniya rechi i glavnye otlichitelnye osobennosti recheporozhdayushchego protsessa [Models of Speech Production and the Main Features of Speech Production Process]. Chelovecheskiy faktor v yazyke: yazyk i porozhdenie rechi [The Human Factor in a Language: Language and Speech Ptoduction]. Moscow, Nauka Publ., 1995, pp. 21-81.

12. Kubryakova E.S. Osobennosti rechevoy deyatelnosti i problemy vnutrennego leksikona [Peculiarities of Speech Production and the Problems of Mental Lexicon]. Chelovecheskiy faktor v yazyke: yazyk i porozhdenie rechi [The Human Factor in a Language: Language and Speech Ptoduction]. Moscow, Nauka Publ., 1995, pp. 82-140.

13. Lapteva O.A. Zhivaya russkaya rech $s$ teleekrana. Razgovornyy plast televizionnoy rechi $v$ normativnom aspekte [Live Russian Speech on Television. Colloqial Layer of Television Speech in the Regulatory Aspect]. Moscow, URSS Publ., 2000. 520 p.

14. Leontyev A.A. Rechevaya deyatelnost [Speech Activity]. Osnovy teorii rechevoy deyatelnost $i$ [Fundamentals of the Theory of Speech Activity]. Moscow, Nauka Publ., 1974, pp. 29-35.

15. Luriya A.R. Yazyk i soznanie [Language and Consciousness]. Rostov-on-Don, Feniks Publ., 1998. $416 \mathrm{p}$.

16. Norman B.Yu. Grammatika govoryashchego [Grammar of the Speaker]. Saint Petersburg, Izd-vo S.Peterburg. un-ta, 1994. $228 \mathrm{p}$.

17. Peshkovskiy A.M. Russkiy sintaksis v nauchnom osveshchenii [Russian Syntax in a Scientific Coverage]. Moscow, Izd-vo Ministerstva prosveshcheniya RSFSR, 1956. $512 \mathrm{p}$.

18. Sakharnyy L.V. Teksty-primitivy i zakonomernosti ikh porozhdeniya [Texts-Primitives and Patterns of Their Generation]. Kubryakova E.S., ed. Chelovecheskiy faktor v yazyke: yazyk $i$ porozhdenie rechi [The Human Factor in Language: Language and Speech Ptoduction]. Moscow, Nauka Publ., 1995, pp. 221-237.

19. Shcherba L.V. Sovremennyy russkiy literaturnyy yazyk [Modern Russian Literary Language]. Izbrannye raboty po russkomu yazyku [Selected Works on Russian Language]. Moscow, Uchpedgiz Publ., 1957, pp. 110-129.

\section{Information About the Author}

Anna E. Tsesarskaya, Assistant Professor, Department of Russian Language as Foreign, Far Eastern Federal University, Sukhanova St., 8, 690950 Vladivostok, Russian Federation, annaceas@mail.ru.

\section{Информация об авторе}

Анна Евгеньевна Цесарская, старший преподаватель кафедры русского языка как иностранного, Дальневосточный федеральный университет, ул. Суханова, 8, 690950 г. Владивосток, Российская Федерация, annaceas@mail.ru. 